\title{
The Ontario New Universities Library Project-A Centralized Processing Experiment Completed
}

\begin{abstract}
This paper was written at the conclusion of ONULP, a short-term centralized processing Project carried on at the University of Toronto Library. The prime functions of the Project were the selection, acquisition, and cataloging of 34,600 titles in 44,510 volumes for each of five new academic libraries in Ontario. The paper charts acquisition figures, describes cataloging practice, and concludes with a comment on the book catalog produced by computer for ONULP.
\end{abstract}

\begin{abstract}
A Ontario, the Ontario New Universities Library Project was organized to provide five new universities and colleges with basic and identical undergraduate library collections. These universities were Brock in St. Catharines, Guelph University and Trent University in Peterborough, plus two new off-campus colleges for the University of Toronto, Scarborough and Erindale. The University of Toronto library undertook the responsibility for the selection, acquisition, and processing of the the materials and, in addition, for the experimental production of a book catalog by computer. A staff of approximately thirty-five people was required to design and carry out the project. The last of these libraries to go into operation was Erindale, which opened in September 1967. Erindale College benefited most as all the books bought through the Project were ready to circulate when the library opened its
\end{abstract}

Mrs. Merry is Head of Technical Services at the University of Toronto Libraries, New University Library Projects. doors. This unfortunately was not the case for the other libraries, two of which opened in September 1964. The project was completed in three and one-half years.

\section{SELECTION}

The Project was restricted to the selection of in-print monograph material. The goal was seventeen thousand five hundred titles in thirty-five thousand volumes for each library. Subscriptions and out-of-print materials were avoided mainly because the Project was a shortterm venture and also because the maintenance of the required files would have been too challenging on a temporary basis for a small technical services staff. The selection was based on the Scarborough College curriculum, which included twenty-six subjects common to undergraduate arts and sciences programs.

\section{Cataloging}

The ONULP collection required little professional cataloging. Some 58 per cent of the 34,600 titles received were in the 
TABLE 1

ACQUisition

\begin{tabular}{|c|c|c|c|c|c|}
\hline Description & Domestic ${ }^{*}$ & British & European & Other & Totals \\
\hline $\begin{array}{l}\text { Book Expenditure }{ }^{\dagger} \\
\text { Per Cent }\end{array}$ & $\begin{array}{c}\$ 969,335 \\
77\end{array}$ & $\begin{array}{c}\$ 93,400 \\
8\end{array}$ & $\begin{array}{c}\$ 167,695 \\
13\end{array}$ & $\begin{array}{c}\$ 23,170 \\
2\end{array}$ & $\begin{array}{c}\$ 1,253,600 \\
100\end{array}$ \\
\hline Volumes Acquired $\ddagger$ & 172,237 & 18,792 & 28,635 & 2,886 & $222,550^{\S}$ \\
\hline $\begin{array}{l}\text { Average cost per } \\
\text { volumell }\end{array}$ & 5.68 & 4.96 & 5.85 & $\ldots \ldots$ & \\
\hline $\begin{array}{l}\text { Cost (above) incl. } \\
\text { discount } \\
\text { Cost incl. binding \# } \\
\text { (av. bind. cost) }\end{array}$ & $10 \%-34 \%$ & 2.12 & 2.20 & $\ldots \ldots$ & \\
\hline $\begin{array}{l}\text { Per Cent } \\
\text { orders unfilled } \\
\text { out of print } \\
\text { cancelled }\end{array}$ & $\begin{array}{c}7 \\
(1643) 5 \\
(642) 2\end{array}$ & $\begin{array}{c}14 \\
(365) 10 \\
(152) 4\end{array}$ & $\begin{array}{c}19 \\
(748) 14 \\
(289) 5\end{array}$ & $\begin{array}{l}\cdots \\
\cdots \\
\cdots\end{array}$ & $\begin{array}{c}(3850) 10 \\
(2757) 7 \\
(1093) 3\end{array}$ \\
\hline
\end{tabular}

- Three principal dealers used-Co-operative Book Centre, Toronto; Blackwell's, Oxford; Nijhoff, The Hague. This simplified procedures but weakened service, particularly with back orders and reports where library control was lost because of lack of automatic claim and cancel period. Such was thought unnecessary with a pre-search in-print acquisition policy.

$\dagger$ Budget total $\$ 1,300,000$. Balance unspent $\$ 46,400$.

$¥ A$ team of five male processors prepared (unpacked, checked, matched order cards, and search reports) 7,500 volumes per month ( 90,000 per yr. or 250 titles in 1,500 volumes per man per month.)

\& Total volumes processed 222,550; total salaries earned in Technical Services $\$ 235,140$. Cost of processing each volume $\$ 1.05$. (Supplies and equipment not included).

$\|$ Over-all average cost per volume $\$ 5.14$.

\# Cloth editions pursued always. American and Canadian paperbacks processed unbound.

* Cancelled-reprinting, new ed. in prep., N.Y.P., out of stock, no report.

University of Toronto library collection. Also 12 per cent of these were new editions and required subprofessional editing. The next 35 per cent were cataloged from Library of Congress proofslips, and the final 7 per cent required professional attention. One professional cataloger, six cataloging assistants, and three revisors, one of whom was professional, were required for this work.

Library of Congress (LC) classification was used with the following modifications: Canadian history was classed in F 5000-5949, English Canadian literature in PS 8001-8549, and French Canadian literature in PS 9001-9549. ( $\mathrm{PZ}$ class was not used for fiction.)

LC subject headings were used but were modified in length for book cata$\log$ production, a concession to the ONULP machine system. The ONULP Subject Authority List printed by com- puter contained 24,600 name and topical headings, scope notes, and references (SEE but not SEE ALSO) and was distributed to each of the participating libraries.

LC cataloging was followed closely, with only slight modifications. Cuttering was changed only where a conflict with the University of Toronto library's shelf list was found or where reasonable expansion was not allowed with the LC number. The latest printing date was used in the imprint and the call number. Certain notes were omitted, and as a concession to the machine system the order of title and author's name was reversed in all contents notes.

Multiple copy cataloging required rigid standardization. Where imprint dates varied between one or two copies of a title the date most common to all five copies was chosen for the catalog 
record. No attempt was made to prepare individual records for the libraries adversely affected by this rule. Each of the 44,510 volumes cataloged for each library was pocketed and labelled, using the Se-Lin label.

ONULP provided catalog card sets ( six cards per set) to three of the participating libraries, in addition to the computer printed book catalogs and shelflist cards. Card reproducing equipment was not located in the department, however, hence catalog card sets were not shipped in their books; the libraries involved complained of shelving delays.

There were several aspects to the success of this centralized processing Proj-

TABLE 2

Operational Time Factors (In Months)

\begin{tabular}{|c|c|c|c|}
\hline 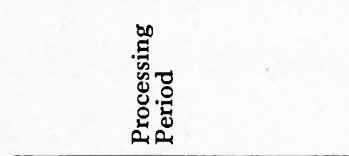 & 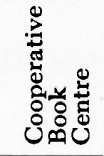 & 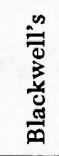 & 䗆 \\
\hline Selection-Ordering & $1 / 4$ & $1 / 2$ & $3 / 4$ \\
\hline $\begin{array}{l}\text { Ordering-Receiving } \\
\text { includes preparation } \\
\text { for cataloging }{ }^{\dagger}\end{array}$ & $2^{1 / 4}$ & $3 \%$ & $6 ;$ \\
\hline $\begin{array}{l}\text { Receiving-Cataloging } \\
\text { includes preparation } \\
\text { for shipping to } 5 \\
\text { libraries } \ddagger\end{array}$ & $2^{3 / 4}$ & $3 / 4$ & $3 \frac{1}{1 / 2}$ \\
\hline $\begin{array}{l}\text { Total Time Factor- } \\
\text { Selection-Cataloging }\end{array}$ & $5^{1 / 4}$ & $7 \frac{1}{1 / 2}$ & $10 \%$ \\
\hline
\end{tabular}

- Foreign items were batch ordered.

$\dagger$ Certain restrictions were placed on each dealer. First, regular orders were not shipped by any dealer until he had all five (or ten) copies of the title in stock. Second, no incomplete orders were accepted unless a report was received in advance enabling ONULP to choose to accept or refuse less than five copies or incomplete multi-volume sets and to report back. Third, no automatic claim and cancel period or replacement program was planned (ONULP was not a continuing service). Fourth, it was not foreseen in the early stages that the budget would provide twice the number of titles originally contracted (a large number for a few dealers). All these factors contributed to high average time lapses between ordering and receiving.

$¥$ Most foreign material required original cataloging. No cataloging priorities were established, hence material with cataloging copy was processed more readily. ect not the least important of which was that it was planned to come to an end. Its policies were not well enough defined to have operated successfully on a continuing basis. The advantages it enjoyed were that it served only a university community, each book collection was new, no subscription files were required, and no individual library idiosyncracies were allowed. Under these conditions the processing was carried out successfully on a steady basis.

\section{Comment on the Machine System}

The computer production of the ONULP book catalogs has been ably described in two or three papers, and does not need repeating here. With the conclusion of the project a few features of the system deserve comment.

Some good features of the system:

1. Full cataloging information was retained in the maih entry records and laid out as in a conventional catalog.

2. Secondary entries were constructed automatically in abbreviated form from the master record.

3. Headings in both catalogs were checked for uniformity by the matching programs, and non-uniform headings were discarded with error messages to ensure correction.

4. Initial articles in twenty-seven languages were disregarded in filing title main and added entries. (Texts in more than one language were manually controlled.)

5. Qualifiers in name headings, e.g. jt. author, ed., comp., were disregarded in filing.

6. Author and title analytics were generated where required.

Some desirable features that were unavailable to ONULP for a variety of reasons, mostly economic:

1. Longer sort fields (maximum was sixty characters, capitals, diacritics removed) to ensure more accurate 
TABLE 3

StafF-Salary Cost ANalysis

Sample Year

\begin{tabular}{|c|c|c|c|c|c|}
\hline Job Description & Salary & $\begin{array}{l}\text { Per Cent, } \\
\text { Section }\end{array}$ & Work Days & $\begin{array}{l}\text { Per Cent, } \\
\text { Section }\end{array}$ & $\begin{array}{c}\text { Per Cent, } \\
\text { Total Salary }\end{array}$ \\
\hline \multicolumn{6}{|l|}{$\begin{array}{l}\text { Acquisition: } 8 \text { clerical staff- } \\
\text { 1963/67 turnover } 13 \text { staff: }\end{array}$} \\
\hline $\begin{array}{l}\text { Preparation of orders } \\
\text { (bibliographical details; } \\
\text { estimate; assign agent), } \\
\text { type order forms, reports }\end{array}$ & $\$ 4,286$ & 19 & 295.5 & 18 & 5 \\
\hline $\begin{array}{l}\text { Books: receiving and processing, } \\
\text { invoice preparation, returns }\end{array}$ & 15,734 & 65 & 1,128 & 72 & 19 \\
\hline $\begin{array}{l}\text { Supervision, revision, statistics, } \\
\text { special jobs }\end{array}$ & 3,339 & 16 & 178.9 & 10 & 4 \\
\hline Totals . . . . . . . & $\$ 23,809$ & 100 & $1,672.4$ & 100 & 28 \\
\hline \multicolumn{6}{|l|}{$\begin{array}{l}\text { Searching: } 5 \text { clerical staff- } \\
\text { 1963/67 turnover } 11 \text { staff: }\end{array}$} \\
\hline $\begin{array}{l}\text { Preparation of titles for } \\
\text { cataloging } . \\
.\end{array}$ & $\$ 14,145$ & 100 & 1,071 & 100 & 17 \\
\hline \multicolumn{6}{|l|}{$\begin{array}{l}\text { Cataloging: } 12 \text { staff incl. } 2 \\
\text { librarians-1963/67 turnover } \\
20 \text { staff: }\end{array}$} \\
\hline $\begin{array}{l}\text { Data sheet preparation and } \\
\text { revision }\end{array}$ & $\$ 12,172$ & 28 & 815 & 30 & 15 \\
\hline $\begin{array}{l}\text { Keypunching and revision, } \\
\text { keypunch training }\end{array}$ & 3,278 & 7.6 & 248 & 9 & 4 \\
\hline $\begin{array}{l}\text { Book shipping, book pockets } \\
\text { and label preparation }\end{array}$ & 7,615 & 16.5 & 567 & 21 & 9 \\
\hline $\begin{array}{l}\text { Master card typing and } \\
\text { revision-sort xeroxed card } \\
\text { sets }\end{array}$ & 6,005 & 9.6 & 375 & 11 & 8 \\
\hline $\begin{array}{l}\text { Filing and revision (master } \\
\text { cards, working shelf list, } 2 \\
\text { authority files, computer } \\
\text { printed shelf list) }\end{array}$ & 2,893 & 6.5 & 236 & 9 & 4 \\
\hline Original cataloging & 2,063 & 4.5 & 92.5 & 4 & 3 \\
\hline Administration $\cdot$. $\quad \cdot \quad \cdot \quad \cdot \quad \cdot$ & 5,045 & 11.1 & 181 & 7 & 6 \\
\hline $\begin{array}{l}\text { Book catalog preparation and } \\
\text { correction (monthly machine } \\
\text { cycle). }\end{array}$ & 3,058 & 12.2 & 156.5 & 6 & 4 \\
\hline Secretarial . . . . & 1,718 & 4 & 85 & 3 & 2 \\
\hline Total . . . . . & $\$ 43,847$ & 100 & 2,756 & 100 & 55 \\
\hline Total Salaries & $\$ 81,801$ & & & & 100 \\
\hline
\end{tabular}


filing particularly in the subject cata$\log$.

2. Consolidation of all titles by one author under his name, listed once.

3. Consolidation of SEE references to avoid waste space.

4. Ability to generate a changed shelflist record for one library at a time and to suppress the record where other libraries not affected; and to keep such changes from reappearing in the book catalogs.

5. Although unchangeable, the rigid automatic filing of the computer, based on spacing and punctuation, is somewhat inconvenient for the catalog user.

6. Although not essential, the lack of
non-Roman alphabets, italics, or printing in red has been noted by some users of the catalogs.

There was general consensus that a book catalog produced monthly was not the most satisfactory index to a working collection, despite its advantage of portability. Also, a sample study in 1964 revealed that the cost of listing 5,220 titles in the book catalogs ( 150 copies) was 1.7 times greater than that of listing the same titles in manually produced card catalogs ( 1 copy). The real future for automating bibliographic records apparently lies in a more detailed, flexible, and enlarged data format, with international compatibility and accessibility. 